\title{
Survivor: Spectators and Gladiators in the US Environmental Movement, 2000-2010
}

\author{
Soon Seok Park and Andrew Raridon \\ Social Movement Studies 16(6):721-734.
}

\begin{abstract}
What motivates people to participate in which forms of environmental activism? To address this question, we revise empirical models examining environmental activism by disaggregating the outcome variable of movement participation and dichotomizing two key motivational factors. Using repeated cross-sectional data from the US General Social Survey of 2000 and 2010, this study conducts logistic regression of four forms of participation on perceived severity and sense of efficacy, while accounting for biographical availability and political engagement. Results from regression analysis show that vocabularies of motive have substantial impacts on an individual's likelihood of: 1) signing a petition; 2) giving money; 3) joining a group; and 4) joining a protest or demonstration. Their effects are large enough to override the noticeable impacts of liberalism and education. This study also finds that the level of participation in the movement across all forms has decreased between 2000 and 2010 . These findings direct our attention to the limited capacity of the public sphere to accommodate the environmental movement during the last decade, as well as to potential changes in environmental activism in the coming decades that may mobilize those previously less likely to participate.
\end{abstract}

Keywords: environmental movement, vocabularies of motive, movement participation, liberalism, education, United States

Correspondence Address: Soon Seok Park, 700 W. State Street Stone Hall 341 West Lafayette, West Lafayette, Indiana 47907. United States

\section{Notes on Contributors}

Soon Seok Park is a doctoral candidate in the Department of Sociology at Purdue University. His research interests include social movements and international political economy. He is currently working on his dissertation entitled "Threat, Memory, and Framing: The Development of South Korea's Democracy Movement, 1979-1987."

Andrew Raridon joins the faculty at Valparaiso University as an Assistant Professor of Sociology and Criminology in the Fall of 2017. His research interests include food and agriculture, social movements, and social inequality. His current work examines market-oriented and lifestyle activism among young farmers across North America, and the dynamics of race, class, and gender disadvantage and privilege within agri-food systems.

Acknowledgements: An earlier version of this paper was presented at the 2016 American Sociological Association Annual Meeting. The authors thank Rachel Einwohner, Kenneth Ferraro, Patricia Morton, Thomas Shriver, Kevin Stainback, Jared Wright, and the editors and anonymous reviewers for their helpful comments and advice. 


\section{Survivor: Spectators and Gladiators in the US Environmental Movement, 2000-2010}

Charges that environmental activism in the US has 'de-radicalized' have fueled debates over the current state of environmental activism. Some optimistically argue that the movement is one of the 'great survivors' of the New Left (Dunlap, 2006; Rootes, 2007a, p. 608). Others surmise that the movement is 'declining' (Brulle \& Jenkins, 2008) or even 'dead' (Shellenberger \& Nordhaus, 2004). A central feature of these debates is the changing role of individuals as environmental activists. Since the 1960s branches of the US environmental movement were bureaucratized and institutionalized via the establishment of formal movement organizations. These organizations helped facilitate access to legislators that ultimately led to keystone environmental policies - accomplishments that many consider to be an indication of the movement's success. However, some contend the tactics many activists currently employ to achieve mainstream legislative success are uncontroversial and non-confrontational, resulting in the proliferation of passive 'checkbook and credit card' activists and an overall decline in the perceived gravity or immediacy of environmental issues (Brulle \& Jenkins, 2008; Edwards \& McCarthy, 2007). Yet amid these claims of the environmental movement's demise, millions still claim to be environmental activists mobilizing for various causes (Rootes, 2007a; Staggenborg, 2008).

In addition to gauging the US environmental movement, these debates concern the frontiers of contemporary social movement activity by questioning what types of activism individuals engage in today and how the framing of issues impacts movement participation. In this article, we engage with these debates by examining participation in the environmental movement and the different forms individual environmental activism takes. We blend two theoretical frameworks to better discern the diversity and intensity of individuals' activism, as 
well as the motivational factors that drive them to action. Borrowing from Barkan's (2004) study of environmental citizenship, we distinguish between 'gladiators' and 'spectators,' or participants who work actively to promote and achieve environmental goals and causes vis-à-vis supporters who espouse such goals more passively. Drawing from Benford's (1993) research on nuclear disarmament movements, we also operationalize two 'vocabularies of motive', or the individuallevel frames that motivate and sustain activists' participation in collective action, to examine how motivational factors impact different types of activists and activism. Together, we consider how vocabularies of motive influence not only individuals' participation in the environmental movement, but whether vocabularies of motive operate differently for passive or active participants, and what this reveals about the nature of collective action overall.

To accomplish these tasks, we use data from the General Social Survey (GSS) of the United States from the years 2000 and 2010 and adjust Barkan's (2004) model, making three important empirical distinctions in the process. First, rather than ask if the US environmental movement as a whole is in decline or not, in this study we consider what types of environmental movement activism individuals are engaged in between the two time points. We do so by differentiating among four different types of environmental activism that vary in intensity: 1) signing a petition; 2) giving money; 3) joining a group; and 4) joining a protest or demonstration. Second, by using the GSS data we are able to operationalize two vocabularies of motive theorized by Benford (1993) into dichotomous measures to examine how different vocabularies of motive influence participation in these four types of environmental movement activism. Third, we explore whether and how important predictors of movement participation vary across these four types of activism.

By making these empirical distinctions, we extend theoretical work examining how and 
in what ways motivational factors such as vocabularies of motive impact both active and passive forms of activism. We also contribute to ongoing work examining changes in the environmental movement and individual environmental activism by demonstrating specific shifts in environmental movement participation over the first decade of the new millennium. In the following sections, we elaborate on the theoretical and analytical frameworks in which we situate our study, explain our data and methodological approach, and present findings. We conclude with a discussion that elaborates on the central aspects of our findings and speaks to the broader debates over environmental activism and general social movement activism that were introduced above.

\section{Participation in the Environmental Movement: 'Gladiators' and 'Spectators'}

The US environmental movement is a massive and diverse umbrella movement that includes groups advocating on behalf of issues ranging from resource conservation, environmental justice, and nuclear weapons disarmament to slowing global climate change, marine overfishing, and toxic waste incineration (Dalton, Recchia, \& Rohrschneider, 2003; Rootes, 2007a). Growing out of early efforts to preserve wilderness areas throughout the US, the modern environmental movement emerged and began to take shape during the 1970s and 1980s following the 'New Left' movements of the 1960s (Staggenborg, 2008). The movement has since grown to encompass 'over 6,500 national and 20,000 local environmental organizations, along with an estimated 20-30 million members...dwarf[ing] other modern social movements such as the civil rights or peace movements' (Brulle \& Jenkins, 2008, p. 1). Accordingly, individuals have participated in a wide spectrum of environmental movement activism ranging from writing letters, signing petitions, donating money, organizing marches and informational sessions, and lobbying for and crafting legislation, to more radical and disruptive tactics such as blocking 
whaling boats, occupying trees slated for destruction, and 'monkey-wrenching' logging and oil equipment (Gottlieb, 2005; Tranter, 2010).

Despite the variety of forms environmental activism can potentially take, some argue that over time aspects of environmental collective action have become institutionalized by environmental SMOs and 'green' political parties and, by extension, overly-reliant on attracting and maintaining 'checkbook' members (Dalton, 2015; Dunlap, 2006; Hensby, Sibthorpe, \& Driver, 2011; Stolle, Hooghe, \& Micheletti, 2005). But does the proliferation of institutionalized environmental organizations and parties also indicate that individuals' participation in environmental activism has declined overall? Considering the pessimistic declarations that the environmental movement is dead, declining, or at best, stagnating due to institutionalization and a decrease in contentious political action (Brulle \& Jenkins, 2008; Rootes, 2007a; Shellenberger \& Nordhaus, 2004), we begin our analysis by examining the change in the level of the environmental movement participation in the US.

In addition to debates over an alleged decline in overall environmental movement activism in the US, some scholars contend that when individuals do engage in collective action their activism is increasingly non-confrontational. In his study of environmental citizenship, Barkan (2004) conceptualizes individuals' differing approaches to environmental activism as the difference between 'spectators' and 'gladiators,' or between individuals who passively espouse environmental concerns and those that become active supporters of environmental causes (Burns, Schlozman, \& Verba, 2001; Saunders, Grasso, Olcese, Rainsford, \& Rootes, 2012; Verba, Schlozman, \& Brady, 1995). However, like many other studies of social movement activism, Barkan relies on a combined measure comprised of several different forms of passive activism, excluding participation in protests or demonstrations. Following previous work that found 
variations in people's support by different forms of activism (Park \& Einwohner, 2015) and variations across other forms of protest (Biggs, 2015; Saunders et al., 2012), our empirical models aim to capture the distinctions among different forms of activism by disaggregating Barkan's combined indicators of environmental activism and differentiating among four types of environmental movement participation: 1) signing a petition; 2) giving money; 3) joining a group; and 4) joining a protest or demonstration. This loosely divides activists into those involved in two more-direct, 'gladiator-type' forms of activism (group membership and protest participation), and those that engage in two 'spectator-like,' indirect forms of movement participation (signing a petition and giving money ${ }^{1}$ ). By explicitly accounting for the different levels of commitment, cost, and risk involved with different forms of activism, we also examine possible variations in the relationships between predictors of participation and different types of activism.

\section{Vocabularies of Motive and Differential Participation}

The social-psychological construction of movement goals and grievances is intricately related to an individual's decision to engage in activism. The framing perspective contends that something must push an individual from passive support of a movement (so-called 'consensus mobilization') towards active participation in the movement (or 'action mobilization') (Klandermans, 1984; Snow \& Benford, 1988). Scholars of framing argue that movements and their participants engage in strategic framing tactics in order to convince, persuade, and motivate individuals towards activism, demobilize opponents, and secure support from unaffiliated third parties (Noakes \& Johnston, 2005; Shriver, Adams, \& Cable, 2013).

In the course of strategically framing movement goals and grievances to encourage individuals to mobilize on behalf of a movement, movement participants create and wield what Benford (1993) calls 'vocabularies of motive'. These vocabularies of motive are individual-level 
'rationales and justifications for their movement participation (or lack thereof)' intended to facilitate and sustain their activism in the face of criticism, difficulty, or defeat (Benford, 1993, p. 200). In his study of the nuclear disarmament movement, Benford identifies four vocabularies of motive that individual activists employ to make sense of their activism: 'severity' amplifies the direness of the issue at hand; 'urgency' keys the necessity of taking swift action; 'efficacy' emphasizes the ability for individuals to make a difference through their activism; and 'propriety' reinforces the need for individuals to take action on behalf of the movement. All told, Benford's vocabularies of motive help explain how activists construct their movement realities in order to justify their actions and their participation in costly activism in the face of adversity.

Scholars have utilized indicators of vocabularies of motive to examine shifts in both public and private environmental activism, although there is variation in how each scholar conceptualizes these key variables. Barkan's (2004) approach includes five-point ordinal scales to measure individuals' perceptions of the severity of environmental dangers and their sense of efficacy to address environmental issues, which he conceptualizes as 'issue engagement' and 'psychological engagement'. These scales closely approximate two of Benford's vocabularies of motive: 'severity' and 'efficacy' respectively. GSS data from the years 2000 and 2010 include measures that represent facets of two of the four vocabularies of motive first laid out by Benford (1993), and thus provide us an opportunity to examine two of Benford's vocabularies of motive in this study.

In our analysis, we argue that Benford's (1993) conceptualization of vocabularies of motive urges us to rethink the operationalization of Barkan's (2004) variables. While it is indeed possible that perceptions of issue severity or personal efficacy range across a continuum, Klandermans's (1984) and Snow and Benford's (1988) distinctions between consensus and 
action mobilization suggest that individuals reach a tipping point at which they decide to engage in social movement activism. Applied to Benford's vocabularies of motive, this suggests that there is a tipping point within individuals' spectra of perceived severity and efficacy that distinguishes between those with clear perceptions of severity and efficacy, and thus a clearer impetus to act, and those with undecided or no perceptions of the severity of an issue or of their efficacy to address it. From this perspective, we operationalize two of the motivational perceptions represented by Benford's vocabularies of motive as discrete binary, rather than ordinal or continuous, variables, and test them with the following hypotheses:

H1: Individuals who perceive environmental problems as severe are more likely to participate in environmental activism than individuals who do not.

H2: Individuals with efficacy of action are more likely to participate in environmental activism than individuals who do not have efficacy of action.

Using this alternative measurement, we hope to better assess what impact two vocabularies of motive may have on individuals and their activities in the environmental movement.

Beyond framing processes, social movement researchers contend that certain individuals may be better disposed to participate as activists because of individual and microstructural factors. Studies concerning 'differential participation' investigate what factors influence an individual's decision or ability to engage in activism (Barkan, Cohn, \& Whitaker, 1995; Cable, Walsh, \& Warland, 1988; McAdam, 1988; McAdam \& Paulsen, 1993). Broadly, differential participation research examines three theoretical constructs: social networks; political engagement; and biographical availability.

Researchers consistently show that individuals with connections to other activists or organizations, and even those with so-called 'weak ties,' are much more likely to be asked and 
subsequently go on to participate in protest than those without similar social network connections (Fernandez \& McAdam, 1988; Granovetter, 1973; McAdam \& Paulsen, 1993; Snow, Zurcher, \& Ekland-Olson, 1980). Social network analyses also demonstrate the importance of an individual's level of 'political engagement' in determining their likelihood of membership in an organization and their overall embeddedness in social networks (Schussman \& Soule, 2005). Political scientists and social movement scholars analyzing the effect of political engagement on individuals' participation find that political liberals and individuals who regularly consume news media are more politically engaged than political conservatives and the less-informed, and thus more likely to engage in protest (Schussman \& Soule, 2005). Finally, 'biographical availability' conceptualizes the individual factors, such as employment, familial obligations, and financial resources, which can make an individual more or less likely to participate in protest. Studies demonstrate that people with children and other familial responsibilities, challenging work schedules, and tenuous financial situations are less likely to be 'available' for protest, whereas those without many responsibilities and with sufficient time and resources, such as students, are better positioned to join a movement (McAdam, 1988; Nepstad \& Smith, 1999; Schussman \& Soule, 2005; Snow et al., 1980)

One way to tap into these concepts of microstructural availability is to account for the relative size of potential movement participants' location and other community factors related to mobilization (Almeida, 2012; McAdam \& Boudet, 2012; van Dyke, 1998). For instance, Van Dyke (1998) found that students attending large universities were more likely to have engaged in protest activities in part because it was more likely there was a 'critical mass' of potential participants to initiate, join, and engage in a movement organization or protest at bigger institutions. Almeida (2012) finds similar trends in Latin America, noting that communities with 
more developed infrastructure were more likely to experience activism in part because there were more community-level resources for activists to draw upon. We complement this established body of research by examining how activists' vocabularies of motive impact their likelihood of participation in four very different types of environmental movement activism.

\section{Data and Methods}

This study tests two formal hypotheses using repeated cross-sectional data of the General Social Survey of 2000 and $2010 .{ }^{2}$ The mean age for respondents is 46 (SD = 16.7) with a range from 18 to 89, the majority of the participants are European Americans or whites (78.5\%), and women are the majority gender $(55.4 \%)$. To best represent the parameters of the population, this study invokes weights and accounts for clustering as recommended by the data source (NORC, 2013, p. 2866). This procedure allows us to avoid bias due to the non-respondent, sub-sampling, and multi-stage sampling design of the US General Social Survey. Table 1 presents the coding, means, and standard deviations of outcome variables in 2000 and 2010. Summary statistics of explanatory and control variables are reported in Appendix A.

\section{[TABLE 1 ABOUT HERE]}

\section{Measurements}

In this study, there are four outcome variables that tap into different forms of movement participation: 1) signing a petition about an environmental issue; 2) giving money to an environmental group; 3) joining a group whose main goal is to preserve or protect the environment; and 4) joining a protest or demonstration about an environmental issue. Respondents reported their current status for group membership and their behaviors in the past five years for the other three. All outcome variables are coded as 1 for participation and 0 for non-participation. As discussed earlier, previous research typically aggregates different forms of 
movement participation as a summated index. This study, however, does not summate them in order to examine the more nuanced relationships between predictors and different types of activism.

This study includes two focal explanatory variables and twelve control variables. Efficacy was measured with two items (Cronbach's alpha $\left.=.64^{3}\right)$ : 'It is too difficult for someone like me to do much about the environment; There is no point in doing what I can for the environment unless others do the same.' They tap into individuals' beliefs in the competence and effect of their action. The original answer categories were from strongly agree (1) to neutral (3) to strongly disagree (5). Neutral response was categorized as lack of efficacy because the present study attempts to distinguish the respondents who had clear perceptions from those who do not. The summated index, therefore, was then transformed into a binary measure using the threshold of 8 out of 10 highest possible points which indicates a clear sense of efficacy, on average, for both items. Likewise, severity is measured with five items (alpha $=.76)$. Respondents rated the first item from strongly agree (1) to strongly disagree (5): 'Many of the claims about environmental threats are exaggerated.' Given the recoding, they were asked to rate following four items from not dangerous at all (1) to somewhat dangerous (3) and to extremely dangerous for the environment (5): a) air pollution caused by cars; b) air pollution caused by industry; c) pesticides and chemicals used in farming; and d) pollution of America's rivers, lakes, and streams. As with the measure of efficacy, an average of 4 is the cut-off point for making a binary variable. The threshold for this summated index was, therefore, 20 out of 25 highest possible points. As a result, efficacy and severity variables are coded as 1 for presence and 0 for absence. In making the key focal variables into binary ones, a possible concern was a small number of cases with 1 as the cut-off point is an upper end. However, as the summary statistics shows, 
substantial portions of respondents have efficacy (.465) and severity (.357) which allowed enough statistical power (see Appendix A).

Twelve control variables are chosen following the literature on 'differential participation' (McAdam, 1988; McAdam \& Paulsen, 1993; Schussman \& Soule, 2005) as well as empirical research on the US environmental movement (Blocker \& Eckberg, 1997; Gillham, 2008; Lubell, 2002; Stern, Dietz, Abel, Guagnano, \& Kalof, 1999; Xiao \& McCright, 2014). The variables representing 'biographical availability' are largely overlapping with demographic and socioeconomic status variables. Therefore, this study includes labor force status, marital status, existence of young children in family, sex, race, age, income, and education. The literature also indicates that those who are 'politically more engaged' are more likely to participate. Previous research uses party affiliation and political views along with political efficacy, interest, and knowledge (e.g. Schussman \& Soule, 2005). The GSS data allow us to include the first two variables (party affiliation and political views) in the empirical models.

The last two control variables are noteworthy. First, the statistical models include a dummy variable of the year 2010. This inclusion enables us to statistically examine the change of the level of environmental movement participation between 2000 and 2010. Second, as noted earlier, this study also accounts for the size of place to predict an individual's likelihood to participate in the environmental movement. Including this variable is a small-but-notable step toward accounting for community-level factors even though the data set does not allow a more sophisticated multi-level modeling.

\section{Analytic Strategy}

Data analyses in this study were conducted in two steps. First, we documented the changes in the level of participation from the years 2000 to 2010. Second, the regression 
analysis was conducted to test two hypotheses. We first tested whether the individual-level relationships have changed from 2000 to 2010, which is a standard procedure for using repeated cross-sectional data (Firebaugh, 1997, p. 42-63). After finding no evidence of change in the relationships, we then conducted logistic regression analysis with the pooled data. Then, by estimating predicted probabilities of outcome variables, marginal effects of key predictors were compared. It should be noted that descriptive statistics adjusted for weighting while regression analyses used un-weighted data as the variables used to construct the weights are in the equation (Winship \& Radbill, 1994).

\section{Findings}

\section{Changes in the Level of Participation}

Table 1 presented descriptive statistics of four outcome variables in 2000 and 2010. It is a consistent pattern that, across all forms, environmental movement participation has decreased from 2000 to 2010. For instance, the percentage of respondents that had given money to an environmental group decreased from 23 percent in 2000 to 18.1 percent in 2010 and the group membership declined from 8.7 percent to 5.3 percent.

Table 2 presents logistic regression results of four types of participation. It also presents statistical evidence for the difference between the levels of participation of 2000 and of 2010. The findings using the 2010 dummy variables confirm that the decreases in signing a petition, giving money, and joining a group are statistically significant. It is only the protest participation model that does not reach the significance level. One notable factor explaining the insignificance is the very small proportion of respondents participating in protest. In sum, the analysis supports the claim that environmental activism has declined since the year 2000.

[TABLE 2 ABOUT HERE] 


\section{Patterns of Environmental Movement Participation}

Results reported in Table 2 support both hypotheses. They show that two key explanatory variables have a positive relationship with all forms of participation in the environmental movement. ${ }^{4}$ Specifically, people with a sense of efficacy of action are 2.2 times more likely to sign a petition than those without a sense of efficacy. The impact of efficacy on other forms of participation is comparable except group membership. Likewise, people with a clear perception of environmental threats as severe are 2 times more likely to join a protest than those without. The impact of severity on other forms of participation is comparable except for signing a petition.

Control variables mostly show expected effects. First, biographical availability has a positive relationship with movement participation. Specifically, those without a young child or children are more likely to sign a petition. The more educated and whites are more likely to sign a petition, give money, and join an environmental group than the less educated and racial minorities, respectively. Sex is not a significant predictor, supporting the perspective that malefemale differences are confounded by other driving factors (Tindall, Davies, \& Mauboules, 2003). However, age is found not significant and is noteworthy. Previous research typically found that age is negatively correlated with movement participation (e.g., McAdam, 1988; Schussman \& Soule, 2005). One obvious difference between previous research and the current study is the inclusion of passive participation. Second, political engagement has a positive relationship with movement participation. Those with more liberal political views are more likely to participate in all forms of claims-making. It is also noteworthy that political views are the best predictor of movement participation among the control variables. Lastly, the size of place has a relationship with signing a petition. Respondents living in a smaller community are less likely to sign a petition (and vice versa). The finding supports the idea of 'availability' at the individual 
and community levels. Though this is not surprising, it offers empirical confirmation of both the theoretical rationale and methodological approach to include community-level factors to better explain individual behaviors.

The findings also present some support for the idea that different forms of participation may have qualitatively different relationships with the predictor variables. Effects of being white and having more education that are positive with other forms of participation are not found in the model for joining a protest. In interpreting this, the small sample size for those who participated in protest should be accounted for. However, more importantly, income, which is positively correlated with signing a petition and giving money, is negatively correlated with joining a protest. ${ }^{5}$ The disaggregation of types of participation allowed us to find more nuanced results concerning the changing effect of income.

A comparison of substantial impacts of statistically significant variables is in order. This study estimates predicted probabilities of participation as the variables of interests change. In addition to the key explanatory variables, education and political views are chosen for the analysis because they are not only statistically significant but also best represent 'biographical availability' and 'political engagement,' respectively. For the outcome variable, giving money is chosen for the purpose of illustration for two reasons. First, empirically, it is not as uncommon as joining a protest or joining a group. Second, though it is a relatively passive form of participation, it is still a commitment and investment that is more significant than signing a petition. Controlling other variables at their means, a person with 20 years of education is 3.6 times more likely to monetarily support the movement than a person with 8 years of education $(33.8 \%$ vs. 9.4\%). Likewise, a person with very liberal views is 2.2 times more likely to monetarily support the movement than a person with conservative views $(26.6 \%$ vs. $12.1 \%)$. It should be noted that 
both predictors have substantial impacts on people's probability of supporting the movement, while education leads to a wider variation.

Next, a combination of variables produces more interesting findings and shows robustness of the effects of vocabularies of motives. A person with 8 years of education with efficacy and severity is 3.7 percent more likely to monetarily support the environmental movement than a person with 20 years of education without efficacy and severity (20.6\% vs. 21.4\%). Likewise, a person with very conservative views with efficacy and severity is 69.3 percent more likely to monetarily support the environmental movement than a person with very liberal views without efficacy and severity (26.4\% vs. $15.6 \%)$. These results show that even though more education and liberal views are associated with higher levels of participation, the effects of efficacy of action and perceived severity are so powerful that they can reverse the impacts of liberalism and education. Table 3 shows the impacts of changes in key explanatory variables on monetary support for the movement. Both tables show similar and substantial impacts of these predictors.

\section{[TABLE 3 ABOUT HERE]}

\section{[FIGURE 1 ABOUT HERE]}

In sum, both hypotheses are supported by our analyses. The analysis gives support to the robustness of the effects of vocabularies of motives on movement participation across different forms of activism. It is most striking that their effects are so consequential that they can override the impacts of other notable factors such as education and liberalism.

\section{Discussion and Conclusions}

Our analyses show that between 2000 and 2010 participation in the US environmental 
movement decreased, but that overall levels of participation remained high, indicating that the movement continues to 'survive' and 'endure' (Dunlap, 2010; Rootes, 2007a). Some would argue that the relative decrease is because of institutionalization of the movement, and that the observed downtick in protest is complemented by institutionalized forms of claims-making (Dalton, 2015; Rootes, 2007b; Tranter, 2010). However, our analysis also finds a decrease in institutionalized forms of activism, such as petition signing and monetary support for environmental organizations. These findings align with those of Dalton's (2015) in his analysis of International Social Survey Program data of environmental activism across eight Western countries, all of which experienced a decrease in both petition signing and monetary donations to environmental organizations between 1993 and 2010 (p. 535-7). However, researchers simultaneously have examined an increase in "individualized" or non-traditional forms of activism, including environmental conservation behaviors, such as recycling (Dalton 2015), and green 'political consumption' (Stolle et al., 2005). All in all, we suggest we might be observing a shift in environmental activism from more collective to more individualized claims-making, rather than the movement's 'decline' or 'death' (Brulle \& Jenkins, 2008; Shellenberger \& Nordhaus, 2004).

We also provide two additional interpretations for the decrease in environmental activism we observe in our analysis. First, it is potentially related to the limited carrying capacity of a public arena (Hilgartner \& Bosk, 1988). At a macro-level, society cannot pay equal attention to all arguably important issues. Therefore, when US society had to deal with national security concerns, financial crises, and other competing issues, the environmental movement could have been failing to get people's attention and, therefore, participation (Brechin \& Freeman, 2004). Indeed, it is hard to deny that the events of September $11^{\text {th }}$ and the resulting 'War on Terror,' as 
well as the 'Great Recession,' have occupied a great deal of the public's attention throughout the better part of the 2000s. Second, the overall decrease in environmental movement participation could be a reflection of a downward part of a cycle of protest. Cycles of protest refer to the ups and downs of magnitude of conflict, its diffusion, the forms of action, and the number of types of movement organizations involved (Tarrow, 1994). It could be the case that simply the movement was not as available as it has been in the public sphere in the past. Still, it should be noted that these two interpretations are not incompatible. In our perspective, it is most probable that the decrease is explained by a combination of movement characteristics and changes in the political environment.

These factors are at the heart of our research questions about the impact of vocabularies of motive on individuals' environmental activism. Our regression analyses with repeated crosssectional data supported both hypotheses related to vocabularies of motive. In other words, this study found that perceived severity and efficacy of action have independent and enduring effects on movement participation, and that the size of the impact is substantial. Estimations of predicted probabilities of movement participation showed the impacts of efficacy and severity can reverse the impacts of liberalism and education. This is not to say that liberalism and education are not substantially impactful, but that the two motivational perceptions are more powerful than liberalism and education in explaining an individual's participation in environmental activism.

The powerful effects of perceived severity and efficacy are important to consider in terms of contemporary debates over the environmental movement and the issues various environmental groups are facing in the new millennium. Some suggest that the increasing political polarization of environmental issues in the twenty-first century is contributing to a decrease in the public's perceptions of the severity of environmental issues (Schellenberger and Nordhaus, 2004). 
However, we suggest that as environmental issues become more universal in nature, particularly the issues stemming from global climate change, future environmental activism may begin to incorporate constituents that were previously hostile to environmental goals and grievances, such as more conservative and less-educated individuals. That is, as those individuals are less able to avoid global environmental hazards in the $21^{\text {st }}$ century, their sense of severity and/or efficacy may reverse the demobilizing effects of political conservatism and lack of education. Similar effects may be observed as environmental risks stemming from hydraulic fracking for natural gas - a process that takes place in predominately rural areas in many conservative statescontinue to intensify and negatively impact more people by contaminating water supplies, land, and so forth. Indeed, Ladd (2014) specifically identifies low education levels as an explanation for the low levels of anti-fracking activity among residents in the Haynesville Shale area in Louisiana. Extrapolating the results from our study, as fracking efforts intensify and potentially negatively impact more individuals, we may begin to observe individuals mobilize against fracking, climate change, and other environmental hazards, despite their conservatism or lower educational levels.

The potential power of vocabularies of motive must be considered in the context of specific forms of activism. In our analysis, we also find that the disaggregation of a movement participation indicator is useful. Our comparison of four regression models shows substantial changes in the public's behaviors toward different forms of claims-making. That is, it is not just the level of participation that decreases as the form of activism become riskier and more direct. Rather, we find statistical evidence that the effect of individual predictors may vary by the form of activism. For instance, income changes its effect from being positive for signing a petition and giving money to being negative for joining a protest. It suggests that disaggregated measures 
allow us to investigate nuanced dynamics of movement participation in ways that an aggregated measure does not (Biggs, 2015; Dalton, 2015; Saunders et al., 2012). In other words, we found differences between environmental spectators and gladiators in regards to their relationships with predictors of participation.

There are several limitations to our approach in this study. Most broadly, this study complements rather than substitutes qualitative studies on the impact of framing and vocabularies of motive. It is well worth noting that while variable-oriented quantitative research produces precise findings, it trades off qualitative depth about social movement processes. In addition, while we find disaggregation of movement participation into separate indicators useful, it still flattens variation within each category. For instance, 'protest' could mean either a peaceful march against climate change or a radical blockade of whaling boats. Similarly, 'joining an organization' could refer to a national-level (institutionalized) environmental group or a local grassroots organization - two very different types of organizations in purpose and form. It remains a challenge for social movement scholars to capture those variations with quantitative data. Second, the GSS dataset, while immensely helpful in many respects, cannot include important variables of interest. For instance, 'social network' was not included in our model. More to our focal interest, while the GSS dataset allows the opportunity to operationalize and test two vocabularies of motive, we were not able to examine Benford's other two variables ('urgency' and 'propriety'). Our study's findings indicate that future analyses would greatly benefit from including these other two concepts.

In closing, we suggest that increased attention to variation across different forms of movement participation should extend from analyses of available data to the collection of original data. This approach to various forms of movement participation could be particularly 
fruitful for analyzing original data on less acknowledged forms of activism. For instance, some activists are directing protest inwardly via personal transformation and lifestyle activism, while others are targeting non-traditional arenas, such as the marketplace, with protest and claimsmaking actions (Haenfler, Johnston, \& Jones, 2012; Raridon \& Mix, 2016; Stolle et al., 2005). Indeed, Dalton's (2015) work illustrates how individualized 'conservation behaviors', such as recycling and reducing reliance on personal automobiles, have increased among environmental activists in Western democracies between 1993 and 2010. Furthermore, social movement scholars are beginning to recognize the breadth and depth of online activism, from e-petitions to hacktivism (Earl \& Kimport, 2011). Are each of these alternative forms of activism fundamentally different from more traditional forms of activism, or from each other as well? And how do vocabularies of motive influence individuals' participation in both traditional and vanguard activism? These variables may not be reflected in widely distributed survey datasets, and thus may have been absent from our empirical purview in quantitative analyses. In short, as social activism continues to change and take different forms, our data collection must attend to these nuances and keep pace with these changes if we are to continue to use large datasets to measure levels of social movement participation in meaningful ways.

\footnotetext{
${ }^{1}$ Though signing a petition and giving money might be more passive participation, those actions are still expressions of social movement adherence and participation in collective claims-making (Ennis \& Schreur, 1987).

${ }^{2}$ The outcome variables of interests are also available from the survey in 1993 and 1994. However, we choose not to use them because 1) 1993 data have an issue of a serious
} 
overestimation of a monetary support variable (NORC, 2013, p. 2420); and 2) 1994 data do not have several items for key explanatory variables.

${ }^{3}$ Cronbach's alpha is a coefficient of reliability or internal consistency among items measuring the same concept. Though this is slightly below an adequate coefficient in social science (.70 or higher), it is largely due to the small number (2) of items available in the data. For more about Cronbach's alpha and summated scale construction, refer to Spector (1992).

${ }^{4}$ We also ran the analysis treating two focal variables as continuous variables and found consistent results. The results are available upon request.

${ }^{5}$ The $p$ value is .053 . 


\section{References}

Almeida, P. (2012). Subnational opposition to globalization. Social Forces, 90(4), 1051-1072.

Barkan, S. E. (2004). Explaining public support for the environmental movement: A civic voluntarism model. Social Science Quarterly, 85(4), 913-937.

Barkan, S. E., Cohn, S. F., \& Whitaker, W. H. (1995). Beyond recruitment: Predictors of differential participation in a national anti-hunger organization. Sociological Forum, 10(1), 113-134.

Benford, R. D. (1993). 'You could be the hundredth monkey': Collective action frames and vocabularies of motive within the nuclear disarmament movement.' The Sociological Quarterly, 34, 195-216.

Biggs, M. (2015). Has protest increased since the 1970s? How a survey question can construct a spurious trend. The British Journal of Sociology, 66(1), 141-162.

Blocker, T. J., \& Eckberg, D. L. (1997). Gender and environmentalism: results from the 1993 General Social Survey. Social Science Quarterly, 78, 841-58.

Brechin, S. R., \& Freeman, D. A. (2004). Public support for both the environment and an anti-environmental president: Possible explanations for the George W. Bush anomaly. The Forum, 2(1), 1-19.

Brulle, R., \& Jenkins, J. C. (2008). Fixing the bungled us environmental movement. Contexts, 7(2), 14-18.

Burns, N., Schlozman, K. L., \& Verba, S. (2001). The private roots of public action: Gender, equality, and political participation. Cambridge, MA: Harvard University Press.

Cable, S., Walsh, E. J., Warland, R. H. (1988). Differential paths to political activism: Comparisons of four mobilization processes after the Three Mile Island accident. Social 
Forces, 66(4), 951-69.

Dalton, R. (2015). Waxing or waning? The changing patterns of environmental activism. Environmental Politics 24(4), 530-552.

Dalton, R., Recchia, S., \& Rohrschneider, R. (2003). The environmental movement and the modes of political action. Comparative Political Studies, 36(7), 743-771.

Dunlap, R. E. (2006). Show us the data: The questionable empirical foundations of 'the death of environmentalism' thesis. Organization and Environment 19(1), 88-102.

Dunlap, R. E. (2010). At 40, environmental movement endures, with less consensus. Retrieved from http://www.gallup.com/poll/127487/environmental-movement-endures-lessconsensus.aspx.

Earl, J., \& Kimport, K. (2011). Digitally enabled social change: Activism in the Internet age. Cambridge, MA: MIT Press.

Edwards, B., \& McCarthy, J. (2007). Resources and social movement mobilization. In D. Snow, S. Soule, and H. Kriesi (Eds.), The Blackwell companion to social movements, (pp. 116-152). Oxford: Blackwell.

Ennis, J. G., \& Schreuer, R. (1987). Mobilizing weak support for social movements: The role of grievance, efficacy, and cost. Social Forces, 66, 390-409.

Fernandez, R., \& McAdam, D. (1988). Social networks and social movements: MultiOrganizational fields and recruitment to Mississippi Freedom Summer. Sociological Forum, 3, 357- 382 .

Firebaugh, G. (1997). Analyzing repeated surveys. Thousand Oaks, CA: Sage.

Gillham, P. F. (2008). Participation in the environmental movement: Analysis of the European Union. International Sociology, 23(1), 67-93. 
Gottlieb, R. (2005). Forcing the spring: The transformation of the American environmental movement. Washington, DC: Island Press.

Granovetter, M. (1973). The strength of weak ties. American Journal of Sociology, 78(6), 1360-1380.

Haenfler, R., Johnson, B., \& Jones, E. (2012). Lifestyle movements: Exploring the intersection of lifestyle and social movements. Social Movement Studies, 11(1), 1-20.

Hensby, A., Sibthorpe, J., \& Driver, S. (2011). Resisting the 'protest business': Bureaucracy, post-bureaucracy, and active membership in social movement organizations. Organization, 19(6), 809-823.

Hillgartner, S., \& Bosk, C. L. (1988). The rise and fall of social problems: A public arenas model. American Journal of Sociology, 94(1), 53-78.

Klandermans, B. (1984). Mobilization and participation: Social-psychological expansions of resource mobilization theory. American Sociological Review, 49(5), 583-600.

Ladd, A. (2014). Environmental disputes and opportunity-threat impacts surrounding natural gas fracking in Louisiana. Social Currents, 1(2), 293-311.

Lubell, M. (2002). Environmental activism as collective action. Environment and Behavior, $34(4), 431-454$.

McAdam, D. (1988). Freedom Summer. New York: Oxford University Press.

McAdam, D., \& Boudet, H. S. (2012). Putting social movements in their place. Cambridge, MA: Cambridge University Press.

McAdam, D., and Paulsen, R. (1993). Specifying the relationship between social ties and activism. American Journal of Sociology, 99 (3), 640-667.

National Opinion Research Center [NORC]. (2013). General Social Surveys, 1972-2012: 
Cumulative codebook. Chicago, IL: University of Chicago.

Nepstad, S. E., and Smith, C. (1999). Rethinking recruitment to high-risk/cost activism: The case of Nicaragua exchange. Mobilization, 4, 25-40.

Noakes, J., \& Johnston, H. (2005). Frames of protest: A road map to a perspective. In H. Johnston and J. Noakes (Eds.), Frames of Protest: Social Movements and the Framing Perspective (pp. 1-32). Lanham, MA: Rowman and Littlefield.

Park, S. S., \& Einwohner, R. L. (2015, August). Explaining the acceptance of protest. Paper presented at the 2015 American Sociological Association, Chicago, IL.

Raridon, A., \& Mix, T. L. (2016). 'That's not grassfed!' Identity formation, maintenance, and cooptation in Oklahoma's grassfed livestock movement.' Sociological Inquiry, 86(2), 141-165.

Rootes, C. (2007a). Environmental movements. In D. Snow, S. Soule, and H. Kriesi (Eds.), The Blackwell companion to social movements, (pp. 608-640). Oxford: Blackwell.

Rootes, C. (Ed.). (2007b). Environmental protest in Western Europe. New York: Oxford.

Saunders, C., Grasso, M., Olcese, C., Rainsford, E., \& Rootes, C. (2012). Explaining differential protest participation: Novices, returners, repeaters, and stalwarts. Mobilization, 17(3), 263280.

Schellenberger, M., \& Nordhaus, T. (2004). The death of environmentalism: Global warming politics in a post-environmental world. Retrieved from http://www.thebreakthrough.org/images/Death_of_Environmentalism.pdf.

Schussman, A., \& Soule, S. A. (2005). Process and protest: Accounting for individual protest participation. Social Forces, 84(2), 1083-1106.

Shriver, T. E., Adams, A. E., \& Cable, S. (2013). Discursive obstruction and elite opposition to environmental activism in the Czech Republic. Social Forces, 91(3), 
873-93

Snow, D., \& Benford, R. (1988). Ideology, frame resonance, and participant

mobilization. In B. Klandermans, H. Kriesi, and S. Tarrow (Eds.), From structure to action: Comparing social movement research across cultures, (pp. 197-218). Greenwich, CT: JAI Press.

Snow, D. A., Zurcher Jr., L. A., \& Ekland-Olson, S. (1980). Social networks and social movements: A microstructural approach to differential recruitment. American Sociological Review, 45(5), 787-801.

Spector, P. E. (1992). Summated rating scale construction: An introduction. Newbury Park, CA: Sage.

Staggenborg, S. (2008). Social movements. Oxford: Oxford University Press.

Stern, P. C., Dietz, T., Abel, T., Guagnano, G. A., \& Kalof, L. (1999). A value-belief-norm theory of support for social movements: The case of environmentalism. Human Ecology Review, 6, 81-97.

Stolle, D., Hooghe, M., \& Micheletti, M. (2005). Politics in the supermarket: Political consumerism as a form of political participation. International Political Science Review, 26(3), 245-269.

Tarrow, S. (1994). Power in movement: Social movements, collective action, and politics. Cambridge, MA: Cambridge University Press.

Tindall, D. B., Davies, S., \& Mauboules, C. (2003). Activism and conservation behavior in an environmental movement: The contradictory effects of gender. Society and Natural Resources, 16, 909-932.

Tranter, B. (2010). Environmental activists and non-active environmentalists in Australia. 
Environmental Politics, 19(3), 413-429.

Van Dyke, N. (1998). Hotbeds of activism: Locations of student protest. Social Problems, 45(2), 205-220.

Verba, S., Schlozman, K. L., \& Brady, H. E. (1995). Voice and equality: Civic voluntarism in American politics. Cambridge, MA: Harvard University Press.

Winship, C., \& Radbill, L. (1994). Sampling weights and regression analysis. Sociological Methods and Research, 23, 230-257.

Xiao, C., \& McCright, A. M. (2014). A test of the biographical availability argument for gender differences in environmental behaviors. Environment and Behavior, 46(2), 241-263. 


\section{TABLES}

Table 1. Coding, Means, and Standard Deviations of Outcome Variables in the US General Social Survey of 2000 and 2010

\begin{tabular}{|c|c|c|c|c|c|}
\hline & \multirow[b]{2}{*}{ Coding } & \multicolumn{2}{|c|}{ Unweighted sample } & \multicolumn{2}{|c|}{ Weighted sample } \\
\hline & & Mean & $\mathrm{SD}$ & Mean & $\mathrm{SD}$ \\
\hline $\begin{array}{l}\text { Signing a petition, } 2000 \\
(\mathrm{~N}=1184)\end{array}$ & 0,1 & .223 & .416 & .231 & .421 \\
\hline $\begin{array}{l}\text { Signing a petition, } 2010 \\
(\mathrm{~N}=1403)\end{array}$ & 0,1 & .170 & .375 & .165 & .372 \\
\hline $\begin{array}{l}\text { Giving money, } \\
2000(\mathrm{~N}=1179)\end{array}$ & 0,1 & .228 & .420 & .230 & .421 \\
\hline $\begin{array}{l}\text { Giving money, } \\
2010(\mathrm{~N}=1415)\end{array}$ & 0,1 & .182 & .386 & .181 & .385 \\
\hline $\begin{array}{l}\text { Joining a group, } \\
2000(\mathrm{~N}=1213)\end{array}$ & 0,1 & .087 & .281 & .087 & .282 \\
\hline $\begin{array}{l}\text { Joining a group, } \\
2010(\mathrm{~N}=1422)\end{array}$ & 0,1 & .055 & .228 & .053 & .225 \\
\hline $\begin{array}{l}\text { Joining a protest, } \\
2000(\mathrm{~N}=1160)\end{array}$ & 0,1 & .032 & .176 & .035 & .184 \\
\hline $\begin{array}{l}\text { Joining a protest, } \\
2010(\mathrm{~N}=1421)\end{array}$ & 0,1 & .022 & .146 & .018 & .135 \\
\hline
\end{tabular}


Table 2. Logistic Regression of Four Types of Participation in the US Environmental Movement, 2000-2010 ( $=1,879)$

\begin{tabular}{|c|c|c|c|c|}
\hline & $\begin{array}{l}\text { Signing a } \\
\text { petition }\end{array}$ & Giving money & Joining a group & Joining a protest \\
\hline Efficacy of action & $2.219 * * *(.290)$ & $2.328 * * *(.304)$ & $1.592 *(.340)$ & $2.140 *(.779)$ \\
\hline Perceived severity & $1.675 * *(.218)$ & $2.204 * * *(.285)$ & $2.026^{*}(.419)$ & $2.041 *(.708)$ \\
\hline $\begin{array}{l}\text { Controls } \\
\text { Labor force status } \\
\text { (R = Full-time) }\end{array}$ & & & & \\
\hline Part-time & $1.281(.256)$ & $1.408(.280)$ & $1.604(.469)$ & $975(.484)$ \\
\hline Not working & $1.069(.252)$ & $1.135(.264)$ & $.684(.309)$ & $.892(.522)$ \\
\hline Keeping house & $1.232(.290)$ & $1.183(.282)$ & $1.154(.431)$ & $1.038(.637)$ \\
\hline Retired & $1.049(.252)$ & $1.047(.247)$ & $1.355(.473)$ & 1.710 (1.107) \\
\hline School & $1.868+(.606)$ & $1.232(.436)$ & $1.388(.794)$ & $.596(.480)$ \\
\hline Marital status & $1.176(.160)$ & $.909(.123)$ & $.833(.179)$ & $.540(.216)$ \\
\hline Young children & $.600 *(.124)$ & $.778(.158)$ & $1.161(.360)$ & $1.031(.505)$ \\
\hline Men (Sex) & $1.136(.148)$ & $1.170(.152)$ & $.919(.190)$ & $1.221(.408)$ \\
\hline White (Race) & $1.710 * *(.298)$ & $1.629 * *(.289)$ & $3.221 * *(1.183)$ & $1.592(.685)$ \\
\hline Age & $.999(.005)$ & $1.003(.005)$ & $1.006(.008)$ & $.977(.013)$ \\
\hline Income & $1.111 \dagger(.062)$ & $1.286 * * *(.077)$ & $1.098(.099)$ & $.803 \dagger(.091)$ \\
\hline Education & $1.158 * * *(.028)$ & $1.142 * * *(.027)$ & $1.110 * *(.041)$ & $1.092(.068)$ \\
\hline Size of place & $.900 * * *(.023)$ & $.972(.023)$ & $.990(.037)$ & $1.010(.063)$ \\
\hline Party affiliation & $1.041(.040)$ & $1.020(.039)$ & $1.009(.062)$ & $1.132(.126)$ \\
\hline Political views & $1.200 * * *(.061)$ & $1.176^{* *}(.060)$ & $1.199 *(.097)$ & $1.437 * *(.183)$ \\
\hline 2010 wave & $.681 * *(.086)$ & $.762 *(.096)$ & $.667 *(.132)$ & $.759(.243)$ \\
\hline Constant & $.005 * * *(.002)$ & $.002 * * *(.001)$ & $.001 * * *(.001)$ & $.002 * * *(.002)$ \\
\hline Pseudo R-square & .134 & .136 & .094 & .143 \\
\hline
\end{tabular}

Note: Odds ratios are shown with standard errors in parentheses. Outcome variables are coded as 1 for participation and 0 for non-participation. $\uparrow \mathrm{p}<.1 ; *^{*}<.05 ; * * \mathrm{p}<.01 ; * * * \mathrm{p}<.001$ 
Table 3-1. Impact of Efficacy of Action, Education, and Political Views on Monetary Support for the US Environmental Movement, 2000-2010

\begin{tabular}{lcccccccc}
\hline \multicolumn{1}{c}{ Efficacy } & \multicolumn{3}{c}{ Efficacy (No) } & \multicolumn{5}{c}{ Efficacy (Yes) } \\
\hline $\begin{array}{l}\text { Years of Education } \\
\begin{array}{l}\text { Political Views } \\
\text { Extremely }\end{array}\end{array}$ & 8 & 12 & 16 & 20 & 8 & 12 & 16 & 20 \\
$\begin{array}{l}\text { Conservative } \\
\text { Slightly Conservative }\end{array}$ & .042 & .069 & .112 & .177 & .093 & .148 & .228 & .334 \\
Slightly Liberal & .077 & .093 & .140 & .229 & .124 & .193 & .290 & .409 \\
& .125 & .195 & .291 & .163 & .249 & .360 & .489 \\
Extremely Liberal & .104 & .165 & .251 & .362 & .213 & .314 & .438 & .570
\end{tabular}

Note: Predicted probabilities are shown. For estimation, other variables are controlled at their means or controlled as balanced for a categorical variable.

Table 3-2. Impact of Perceived Severity, Education, and Political Views on Monetary Support for the US Environmental Movement, 2000-2010

$\begin{array}{lll}\text { Severity } & \text { Severity (No) } & \text { Severity (Yes) }\end{array}$

\begin{tabular}{|c|c|c|c|c|c|c|c|c|}
\hline $\begin{array}{l}\text { Years of Education } \\
\text { Political Views }\end{array}$ & 8 & 12 & 16 & 20 & 8 & 12 & 16 & 20 \\
\hline $\begin{array}{l}\text { Extremely } \\
\text { Conservative }\end{array}$ & .047 & .077 & .124 & .194 & .097 & .155 & .238 & .346 \\
\hline Slightly Conservative & .063 & .103 & .164 & .249 & .130 & .202 & .301 & .422 \\
\hline Slightly Liberal & .086 & .137 & .213 & .315 & .171 & .260 & .373 & .503 \\
\hline Extremely Liberal & .115 & (180. & 272 & .388 & 222 & .326 & .452 & .583 \\
\hline
\end{tabular}

Note: Predicted probabilities are shown. For estimation, other variables are controlled at their means or controlled as balanced for a categorical variable. 
Figure 1. Impact of Perceived Severity, Education, and Political Views on Monetary Support for the US Environmental Movement, 2000-2010

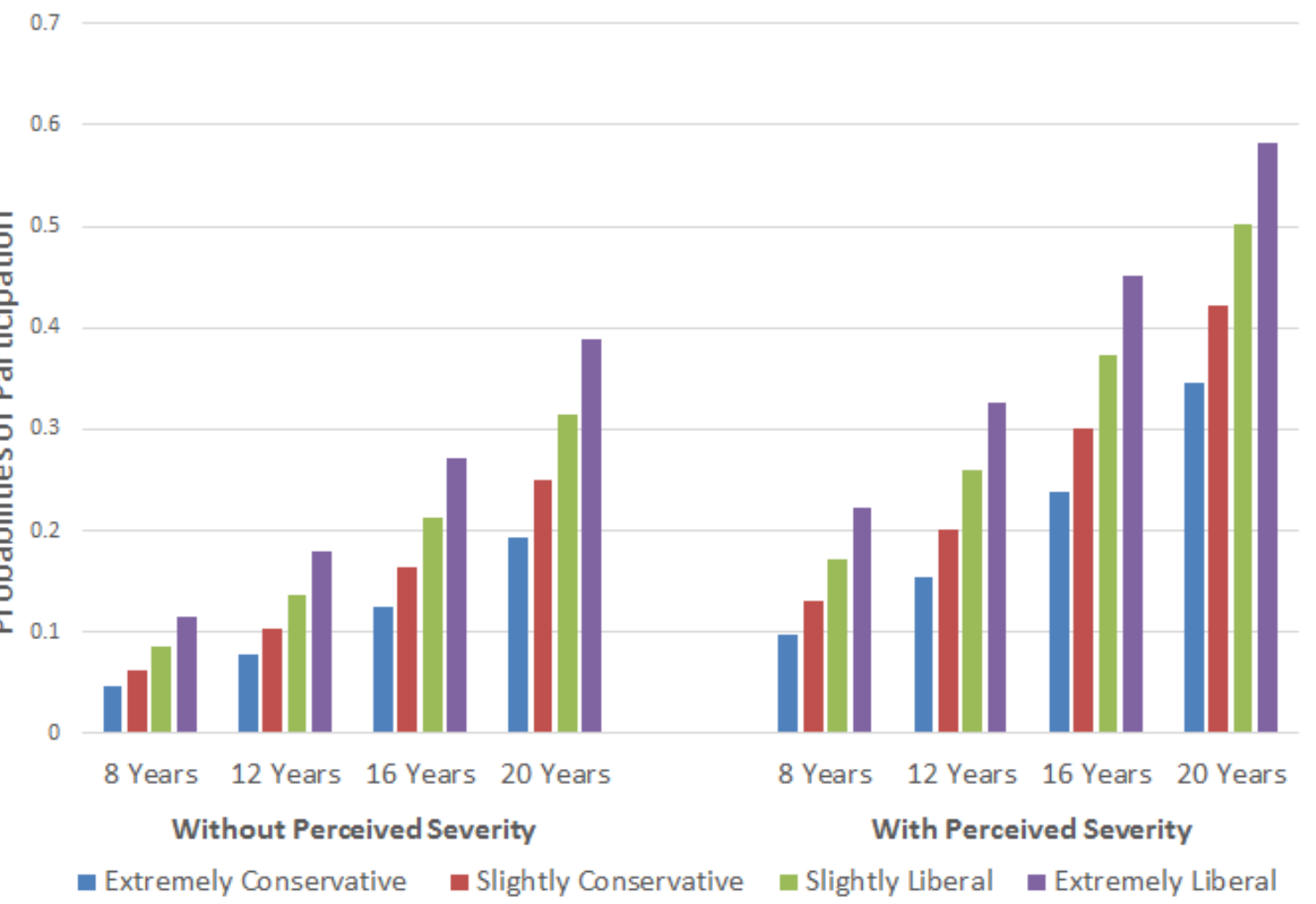




\section{APPENDICES}

Appendix A. Descriptive Statistics for all Independent and Control Variables, 2000-2010 $(\mathrm{N}=\mathbf{1 , 8 7 9})$

\begin{tabular}{lllll}
\hline Variable & Mean & SD & Min & Max \\
\hline Efficacy of action & .465 & .499 & 0 & 1 \\
Perceived severity & .357 & .479 & 0 & 1 \\
Controls & & & & \\
Labor force status & 2.303 & 1.632 & 1 & 6 \\
Marital status & .437 & .496 & 0 & 1 \\
Young children & .150 & .357 & 0 & 1 \\
Sex & .446 & .497 & 0 & 1 \\
Race & .785 & .411 & 0 & 1 \\
Age & 46.056 & 16.657 & 18 & 89 \\
Income & 4.168 & 1.381 & 1 & 5 \\
Education & 13.643 & 2.901 & 0 & 20 \\
Size of place & 4.154 & 2.781 & 1 & 10 \\
Party affiliation & 4.236 & 1.993 & 1 & 7 \\
Political views & 3.908 & 1.436 & 1 & 7 \\
2010 wave & .568 & .496 & 0 & 1 \\
\hline
\end{tabular}

